\title{
Anna Pavlova, Live in Manila!:The Globalization of Ballet and its Localization in the Philippines
}

\author{
Joelle Florence Patrice Jacinto \\ University of the Philippines \\ e-mail: joelle.jacinto@gmail.com
}

Published online: 30 June 2020

Cite this article (APA): Jacinto, J. F. P. (2020). Anna Pavlova, live in Manila!: The globalization of ballet and its localization in the Philippines. Jurai Sembah, 1(1), 35-45. https://doi.org/10.37134/juraisembah.vol1.1.4.2020

\begin{abstract}
Anna Pavlova was the first ballerina to tour the world, effectively globalizing ballet and transforming it from a European/Russian art form into a universal one. The places that she performed in, exotic, war-torn or on the brink of a civil revolt, with either unbearably hot or achingly cold climates, all received her differently, according to the local culture, affecting the ballerina as much as she had an effect on the people who came to see her dance. In most places, such as Cuba, Argentina, the US, Australia, and the Philippines, Pavlova had inspired the localization of ballet in their respective cultures, where appropriation had turned into tradition. This paper looks at how Anna Pavlova accomplished the globalization of ballet as a universal art form, and how it had successfully embedded itself as a local tradition in several countries, specifically in the Philippines, where there exist three professional ballet companies that are still currently active. This paper analyzes Pavlova's contribution using the concepts of globalization, culture contact, and localization or indigenization.
\end{abstract}

Keywords: Anna Pavlova, ballet, Filipinization, Filipino ballet, globalization, indigenization

\section{Introduction}

There are no swans in the Philippines; or rather, they are not native to the region, and any swans in the country that are cited in the Clements Checklist of Birds of the World (2019) are said to be there accidentally. However, the swan is not an unfamiliar concept to the educated Filipinos; many know what a swan looks like, having encountered drawings in picture books as children, and in ballets. It is not strange to be familiar with fanciful birds; similarly, Filipinos know that a sarimanok is a colorful, magnificent bird significant in Maranao legends, and have a concept of what it looks like, also from drawings, as the sarimanok does not actually exist. A Filipino might recognize a swan and differentiate it from other long-necked, aquatic birds, without having seen one. For example, if the likeness of a swan is in a ballet, it is definitely a swan, without a doubt, not a goose or a duck.

Ballet is also not an unfamiliar concept to Filipinos, with three professional ballet companies currently performing in regular seasons in the heart of Metro Manila, and on sporadic national and international performance tours, as well as numerous ballet schools established in almost every major city across the nation. Like swans, ballet was introduced to the Philippines, but while its arrival may have been incidental, it had embedded itself in the culture and may even be considered as a local tradition, given that its presence in the country already spans over a hundred years. A hundred years is certainly enough time for a tradition to cultivate, but not all Filipinos would agree that ballet could possibly become a Philippine tradition, given the era it was introduced and the conditions in which it was developed and promoted.

In 1922, the Russian ballerina Anna Pavlova came to the Philippines and danced with her touring company at the Manila Grand Opera House. She was on her first "Far Eastern tour" (Money, 1982, p. 307) and came by boat - airplanes had been invented by this time, but not yet used for transportation. That she had come to Manila at all implies that there was enough of an audience willing to receive her. That there were several performances scheduled implies this as well, and that the audience was unwilling to watch the 
shows in which she was not performing (these were apparently announced in advance) (p. 310) implies that the audiences in Manila understood that they were buying tickets not just for an unfamiliar new art form, but for that art form's star.

It is unclear how many of these audiences were Filipinos, and how many were foreigners who lived in Manila, but there was certainly much excitement, even if it was merely second- or third-hand information spread by word-of-mouth. It was during the early stages of the American colonial period, and while Filipinos were absorbing the new foreign culture with varying degrees of reception and resistance, spectacular new discoveries were most likely welcome as Filipinos love spectacle. The star of the Russian ballet was coming all the way to the Philippines to dance! How exciting!

Pavlova's performances must have lived up to the hype, for there is no report that she was a disappointment, and dance scholar Basilio Esteban Villaruz (1991) describes her impact on the Philippines as "(a) more inspired and sustained influence" (p. 248) and "inspired many a young girl" (p. 48). There is not much documented during this period, so Villaruz was only able to name one such inspired young girl: Anita Kane, who is only known to us because she established one of the first ballet schools and dance companies (if not the first dance company) in the Philippines, and choreographed the first full-length ballet with a Filipino theme. A few years later, Luva Adameit, who claimed to have been part of Pavlova's company who danced during the 1922 visit, arrived in the Philippines with a manager and a pianist, established her own ballet school, and taught Filipino girls who are now known as "the first generation of Philippine ballet teachers and choreographers" (Villaruz, 1994, p. 49).

Hence, Anna Pavlova had contributed to ballet's establishment and development in the Philippines, both directly and indirectly. The objective of this paper is to highlight the significance of Anna Pavlova's world tour, how her desire to perform for and be applauded by audiences outside Europe affected the remarkable expansion of an art form. This paper looks at these contributions and their consequences to further understand how ballet had become a bearer of Philippine culture. It looks at both the globalization of ballet through Anna Pavlova's pioneering efforts, effects of contact with cultures unfamiliar with the art form, and the localization of ballet into the Philippines.

The modernization afforded by the American colonial period made it possible for Pavlova, and later other international dance personalities, to come to Manila for performances, and for various Russian and English ballet teachers to come to the Philippines to teach classes and establish schools. However, their reluctance to grant independence to the Philippines also cultivated a nationalist attitude towards culture that turned to nativism or, to some extremes, primitivism. Determined to prove their capacity for selfgovernance, nationalist Filipinos worked towards reclaiming a national culture, specifically a precolonial Filipino culture and identity. Proving that ancient Filipinos already possessed a rich, functional civilization before the arrival of foreign influences seemingly substantiates the Philippines' right to independence and self-government, and it was this national identity that was pursued and promoted henceforth. It is during this era that Francisca Reyes Aquino (1983) had started to collect and document "traditional" dances from all over the country, which were published in several volumes of instructional books that would provide repertoire for folk dance companies, led by the Bayanihan now-National folk dance company, propagating images of the Filipino in diverse dance suites. Despite the arbitrary collection of dances, this became what is known as Philippine dance, and did not allow other possible identifications. Ultimately, as gleaned from introductions to Reyes-Aquino's volumes of Philippine Folk Dances, the collection of these dances was meant to save Philippine dances from obsolescence in a period of rising infatuation with American culture - jazz music, vaudeville entertainments, and ballet.

To further the view of ballet as a foreign art form, ballet was prioritized and popularized in the Cultural Center of the Philippines (CCP), which was built in 1969 under the directive of what Gerard Lico (2011) called a "palingenetic ${ }^{1}$ assertion of greatness through the (Marcos) regime's invocation of the archaic and the indigenous..." (p. 172), and was actually the first "megalithic" structure that "promote(d) the image of the nation as a progressive economy in the Third World" (p. 173). Associated with the CCP and the Marcoses, ballet was then seen as an elitist art form that could only function as "entertain(ment for) the bourgeoisie" (Lumbera, 2000).

It is not entirely true that ballet can only be practiced and enjoyed by those of the elite upper classes, with local companies building repertoires of ballets with Philippine themes, often performing outside of the $\mathrm{CCP}$ and reaching out to audiences of other social classes and in different regions around the country, for their appreciation and education. Additionally, many of today's professional ballet dancers come from middle and lower-middle social classes as well, with the establishment of scholarship programs for streetchildren in the cities of Quezon City, Manila, Mandaluyong, and Las Piñas. This paper also looks at 
how ballet has transformed to adapt to Philippine culture, and how it has become a part of the culture, a part of the Philippine way of life.

\section{The Globalization of Ballet}

When Anna Pavlova embarked on her first trip out of Europe towards New York, the word "globalization" had not yet been invented, nor had she any idea of the significance of venturing farther around the world other than her anticipation of new audiences to perform for. Some argue that globalization is only a recent development, particularly upon its rapid development in the 1970s, as a new economy had surfaced with the opening of the world market in the 1970s, and the "emergence of new digital networks palpably increased the pace of globalization" (Roldán, et al., 2018, p. I). Melê Yamomo, in his Theatre and Music in Manila and the Asia Pacific, 1869 - 1946: Sounding Modernities (2018), which may be considered in a survey of literature related to this paper due to its concern with transnational opera companies giving performances in 19th century Manila, suggests that early modern globalization should count the first circumnavigation of the globe by Ferdinand Magellan's expedition, and therefore be "premised on the Spanish empire's establishment of Manila as the first instance of global economic and cultural integration" (p. 4). This is in contrast to the more popular acceptance of the mid-19th century as the "more logical beginning of a global interconnection," after Anglo-centric historians, "not just of trade and economy, but of cultural production and consumption."

Indeed, it is during the late 19 th to early 20 th century that many theater producers, Sergei Diaghilev included, were eager to transport Anna Pavlova by boat and train to perform in different cities, at first in Europe and North America, and later to South America and Asia, making Pavlova the most travelled artist amongst her peers and the first to dance all over the world.

But this accomplishment is not merely a record of miles travelled. Globalization is not a concept as simple as circumnavigating the globe, it has elaborated economic, political, cultural and social dimensions. Anthony Giddens (1990) defines globalization as "the intensification of worldwide social relations which link distant localities in such a way that local happenings are shaped by events ocurring many miles away and vice versa" (p. 64). This notion of simultaneity in a globalized world is noted by Helena Wulff (2014) in an ethnographic essay on ballet and funding, that in comparing dancers of ballet companies in London and Paris with dancers of American Ballet Theatre, she had found that the dancers were aware of their "company space and its relationship with other ballet centres, thus suggesting that globalization and transnationality do not necessarily imply deterritorialization or the loss of identity" (Kringelbach and Skinner, 2014, p. 16). Wulff's "Ballet Culture and the Market: A Transnational Perspective," is part of a collection of essays in Dancing Cultures: Globalization, Tourism and Identity in the Anthropology of Dance, edited by Kringelbach and Skinner, offers several perspectives on, and models and examples of the dancing body moving through space and place, as well as dancing as a touristic come-on in several locations, and the role of nation and identity in dance practices in Senegal, Mexico, Korea and Bali (Kringelbach and Skinner, 2014).

Other works that may be seen as related literature may be found in an early collection of writing on globalization in dance is found in Dance Research Journal volume 34 in 2002, when scholars of the Congress on Research in Dance (CORD) were beginning to articulate ideas of globalism and globalization in their research, specifically in essays on breakdancing, Bharatanatyam and somatic practices. In an introduction to the volume, Barbara Browning (2002) enumerates other scholars who have written about dance's "place," including Sally Ann Ness, Yvonne Daniel and Marta Savigliano, whose works looked at "national dance" from external perspectives informed by "touristic, political and economical pressures" (p. 12). Also interesting is Judith Hamera's Dancing Communities: Performance, Difference, and Connection in the Global City (2007), which discusses several dance practices that exhibit transformations of culture through globalization, all of these dance practices are situated in Los Angeles.

As seen in the examples of related literature, Giddens (1990) implies that the impact of globalization is powerful enough to bring about change. This is echoed in the introduction of Helene Nevau Kringelbach and Jonathan Skinner's discussion of dance, culture and globalization, where "dance practices move and become globalized as a result of the mobility of those who perform them..." and "(i)nevitably, those practices become transformed in the process..." (2014, p. 13).

These transformations occur within the localization of the dance practices in the places where they have been brought and performed. In discussing the significance of Anna Pavlova's international tours on the development of ballet as a universal art form, it is also imperative to understand the result of culture 
contact, when ballet was presented to the receiving cultures. Localization and indigenization are concepts related to globalization; this paper will specifically analyze the localization of ballet in the Philippines and show that it is more than just an imitated Western entertainment, of which Filipinos are so fond.

Before Pavlova arrived in the Philippines, she spent a few weeks in Japan, and then China. Prior to this, she had already toured Europe and the United States and Canada several times since 1908, and her success in North America allowed her to continue to South America, performing in Cuba, Costa Rica, Panama, Ecuador, Peru, Chile, Argentina, Brazil, Uruguay, Venezuela, Puerto Rico, and Mexico from 1917 to 1919. After her lengthy "tour of the Orient," she journeyed to South Africa, Australia and New Zealand, and in between regular seasons in London and tours of Europe and North America, she managed to return to South America, Egypt, and Asia. These were made possible by her immense artistic talent, but also by her willingness to travel and experience new audiences and cultures.

It was Pavlova herself who first suggested to the Imperial Ballet at the Maryinski Theate, where she was featured as one of their star ballerinas, that she does a tour of Europe. She was drawn to having new audiences see her dance, and at this time, her local fans had grown exponentially and there was universal acknowledgment of her mastery. As she stepped onto unfamiliar stages outside of Russia, she was met with enthusiastic audiences, recurrently including kings and queens, a clear indication that Pavlova was an artist worthy of royal attendance. Soon, booking and business managers of various theaters, and impresarios like Diaghilev, were outdoing each other to get Pavlova to commit to them, and she did her best to accommodate all into her schedule. ${ }^{2}$

The influence that Anna Pavlova had impressed on other peoples as she jaunted between continents was specific to her. She was not the only ballet dancer traveling for performances at this time; her senior at the Maryinsky, Olga Preobrajenskaya also toured Paris, London and Milan, as well as the United States and Egypt, while a junior, Lydia Lopokhova, briefly left the Ballet Russes to perform separately in the U.S., where she eventually settled down as an emigré. Besides these, Diaghilev's Ballet Russes, performing extensively in Europe and in North and South America, was more impressive and influential as a company presenting fully-realized theatrical work. If Anna Pavlova was possibly more influential than the Ballet Russes, it had more to do with the fact that she went further than these other performers, both logistically and in her involvement with the cultures of her audiences.

As Keith Money (1982) details in his biography of Pavlova's life, ballet itself was not so impressive and extraordinary to persuade unacquainted audiences to fall in love with the art form. Certainly, much of the marketing was to hype up this exceptional Russian ballerina, but while all of high society will come to see her, people came mostly because they were curious. Was she really this brilliant, as everyone says? Reviews of her performances were not only always favourable, but often described her as an otherworldly creature if not a genius, able to " $\mathrm{h}(\mathrm{o}) \mathrm{ld}$ her audience astounded during the forty minutes" (p. 110). She was the main attraction, and audiences only came to watch her. Agnes de Mille (1980) describes how in the U.S., "an entire generation of girls, myself among them, owed their initial enthusiasm for dancing to seeing her in local, extraordinary places" (p. 76). Money mentioned incidents in Paris and Berlin where people went to the theater to ask if "Mlle. Pavlova" was performing that evening and refused to purchase tickets if she wasn't. Similarly, in Manila, announcing that Pavlova would not appear in certain performances yielded low ticket sales.

Anna Pavlova's distinction of having been the first ballerina to dance around the world was only possible because she was the kind of person she was, not just a gifted artist who enraptured audiences, but also as someone who had the means to make it happen. Perhaps it began with curiosity and an ambitious desire to widen the scope of her admirers, as she accommodated agents and producers, her main and only responsibility was to appear at the dates and dance. But soon, she was also putting up her own money to partially finance the trips, sourcing out musical directors and ballet masters, programming what dances to perform, and who was to partner her. Initially, she was not involved in choosing the dancers who would join her tours, both the Polish, Russian and English girls and handful of boys who would accompany her or the local dancers who would fill up the spaces in the corps de ballet, but she was more involved in such processes later. She was demanding of these dancers, for she always felt that the art form she presented to the world, that represented Russia, had to be of the best quality. One rehearsal found her sternly scolding a young dancer whose feet were aching, "You want to be in Madame Pavlova's company. Then you must be artist!" (Money, 1982, p. 255)

Diaghilev had first envisioned that Anna Pavlova was to be the star of his revolutionary Ballet Russes, that the entire enterprise of this touring company would only work with her at its center. She danced a season with him in Paris in 1908, and again in London in 1911, partnering Vaslav Nijinsky, but she 
decided to stop considering Diaghilev's offers as they conflicted with many other offers to perform, particularly in North America. Pavlova's respect for her art form can be seen in how she monitored the Ballet Russes' activities and touring schedule, purposely to avoid being in direct competition with them.

After all, she was not constantly touring merely out of vanity. Pavlova seemed to have made it her mission to bring ballet to as many people as possible. Her touring was not simply one aspect of her career, it was the basis of her career, and she continued to tour for over twenty years, and was on tour at the time of her death in 1931. After five years of performing throughout Europe and coast-to-coast in Northern America, she returned to dance a season at the Maryinsky, where she was still a principal ballerina ${ }^{3}$; she was received by the Tsar Nicholas II, who asked her to stay and dance in St. Petersburg for longer, which Pavlova kindly rejected because she was already committed to a schedule. All the Tsar could say in response was, "Well, come and dance for me again in September, before you go to America." (Money, 1982, p. 174). She wasn't able to fulfill that request either, and only danced for him again a year later.

Money (1982) describes her as having "a fervor about the very act of dancing that was akin almost to a religious mania" (p. 75). She was always very serious about her art and deeply concerned about how it is received. As early as 1909, the first time she performed for King Edward VII and Queen Alexandra in London, she was said to feel that she "was representing Russia" (p. 93). In 1917, still on tour in the midst of World War I, Money offered that she pressed on because she did not feel that she was "a fugitive from Russia, she was a missionary; and that being so, it was not difficult to view the whole world as being peopled by the unconverted" (p. 257), or at least by those who had not yet seen a ballet. She did not only dance for royalty but for whoever could come. In 1916, she spent five months dancing at New York's Hippodrome alongside vaudeville acts and parading elephants. In 1917, she performed for both upper and lower classes in Guayaquil, Ecuador, who were separated by a screen so that the rich landowners and cocoa merchants would not catch contagious diseases from the working class.

Certainly, traveling was not easy back then. The U.S. had joined World War I in 1917, and the Atlantic was a veritable war zone. As Pavlova and her company sailed from one South American port to the next, they were also impeded by various passport regulations that depended on the alliances of each new port of entry. Perhaps Pavlova was undeterred by war as she had been in Germany on the day they declared war in Russia in 1914, was arrested for being a Russian national and deported to London. Moreover, aside from falling empires and warring states, she had to contend with revolutions, rail strikes, epidemics, and the trouble of transporting costumes for 20 ballets in her repertoire. There was far too much danger and effort involved if it was only for applause.

\section{The Bayadere Comes to India: An Interesting Point of Culture Contact}

Anna Pavlova is famous for her solo, The Swan, also known as The Dying Swan, ${ }^{4}$ which was choreographed for her by her former partner and good friend, Mikhail Fokine, and which she performed to countless adoring audiences all over the world. It is notable for the juxtaposition of both fragility and pathos that exists in her body as she flutters through the dance, as an ethereal creature agonizingly resisting and finally succumbing to her death. The image of the Dying Swan is what many associate her with, and a work that she could hardly remove from her programming, due to popular demand.

Fokine choreographed this solo for her when Pavlova was already an established and beloved ballerina at the Maryinsky. What brought her to prominence was the role of Nikiya, the temple dancer, in La Bayadere, a three act ballet that was set in India, or what Petipa and his collaborators imagined India to be. Pavlova's Nikiya was a success, exceptionally remarkable as the ghostly shade in Act III. She was regarded a weak dancer because of her frail appearance (ballerinas of this period were rather voluptuous and muscular), but she used her fragile qualities to full effect and Nikiya became a signature role, alongside The Dying Swan, and the other supernatural ballet icon, Giselle.

La Bayadere must have had an even more profound effect on Pavlova, as evidenced by her anticipation of visiting India in 1923, hoping to see for herself all the orientalist fantasies that were employed in the exotic ballets conjured by Petipa and other ballet masters. But it was not only India that she looked forward to. Apart from her sense of duty to bring ballet to as many audiences as possible, Anna Pavlova was genuinely interested in other cultures. This was seen in how she consistently forced her dancers to go sightseeing and visit local museums and points of local interest, quizzing them on their impressions afterward. She made it a point to see local dances, especially. She was very enchanted with the native practices she found in Japan, but quite disappointed in Burma and India. 
Indian classical dances were discouraged and became a target for suppression as early as the $1890 \mathrm{~s}$ by British missionaries, as well as Indian intellectuals who wished to emulate their colonizers and supported Western reform (Srinivasan, 1988). When Pavlova arrived in India and requested to see their local dances, what they showed Pavlova were inventions that did not at all resemble Bharatanatyam, Kathak, Odissi, Kuchipudi, or any of the other classical dances, which were all finally banned in $1910 .{ }^{5}$ Despite her disappointment, Pavlova would encourage Indians who approached her to learn ballet to seek out and learn their own neglected dances instead, notably Rukmini Devi, who is considered an influential figure in the revival of Bharata Natyam, and Leela Sokhey, who is credited for the revival of Kathak (Fisher, 2012).

India's impression on Pavlova was still quite immense, as she was compelled to create three short ballets after this visit, collaborating with musician Commalatta Bannerjee and Uday Shankar, whom Pavlova had convinced to dance with her, and also co-choreograph some of the ballets (Money, 1982; Erdman, 1987; Fisher, 2012). Joan Erdman opines that compared to the Orientalist hybrid ballets "which Indians never confuse with their own dancing traditions," Pavlova's "experiments" were "appreciated attempts' to incorporate Indian themes and stage effects" (Fisher, 2012, p. 44), and helped revive an interest in Indian dance as "internationalism propelled the popularity of the oriental dance back to India" (Erdman, 1996, p. 300; Fisher, 2012, p. 44).

Even before globalization, ballet imagined itself as a bearer of different world cultures, albeit mostly fantasies of its creators than based on the real world. Asides from the Hindu Nikiya and the German Giselle, Anna Pavlova had also portrayed the Spanish señoritas Paquita in the ballet of the same name, and Kitri in Don Quixote, the Hungarian Raymonda, the French Lisé in La Fille Mal Gardée and Armida in Le Pavillon d'Armide, and even more fantastically, the Egyptian princess in The Daughter of the Pharoah and the slave Veronika in Egyptian Nights/Cleopatra. Theories of appropriation were not yet problematized when Pavlova learned these ballets, and she performed these without any sense of irony, understanding them simply as balletic tradition and how to entice new audiences to the theater.

\section{“National" Dances and "National" Ballets}

Anna Pavlova had a clear concept of "national dances" as folk dances specific to a region that can represent the people who practice it, and, similarly, ballets that could represent or belong to a/any nation. At the Imperial theater, she was learning ballets that were created by a French ballet master, and spent summers in Milan to strengthen her dance technique under the "Italian school." As she was part of the most prominent and prestigious ballet company of the time, it must have been clear to Pavlova that ballet did not belong exclusively to any specific country, not to the Russians, who only expanded the art form from the French, and not even the French, who had only codified and institutionalized what they had adapted from the Italians.

The structure of classical ballet also allows this flexibility. Ballet's movement vocabulary ${ }^{6}$ is very strict and specific, but without tampering with or compromising the basic techniques and principles, can be embellished with certain changes of head and hand gestures and motifs, and the inclusion and balleticization of folk dance steps. For example, the stiff and angular carriage of the arms characteristically found in the Hungarian czardas that is used while a ballerina executes relevé passés en pointe ${ }^{7}$ is a Hungarianization of classical ballet as seen in Petipa's Raymonda. Additionally, these "national" ballets are literally dressed up in national costumes and the stage is designed to set the ballet in the Hungarian palace/French town/Indian temple where the story takes place.

The format in which ballets are presented also allows a customization of design elements. Marius Petipa's ballets, which had become the standard of that era, were made up of three or four acts or scenes that effectively told a story. These stories were told originally through pantomime, but over time, choreography had been adapted so that the story was embedded in the dancing, told through the movements themselves. When Fokine started to create his shorter ballets, he did not need to tell a story, but the dancing instead showed and evoked emotions, as seen in Pavlova's Swan, which was not initially titled The Dying Swan, and somehow upset early audiences when they realized what was happening to their favourite dancer.

When the Imperial Ballet school was established in 1738, it was so that Russia could have its own ballet company. The first ballet masters were all French, including Petipa, its most influential director, whose ballets glorified royalty to please the Tsar: The Sleeping Beauty, ${ }^{8}$ Don Quixote, La Bayadere, Swan Lake, to name a few, all have sections where the dancers walk around in a procession, then bow in reverence to a princess, prince, queen, king or knight, usually the entrada at the start of a divertissement or a series of dances that diverts the audience from the story. "Russian Ballet" often includes this period that Petipa 
presided over, but also when the Russian dancers began to perform outside Russia with Diaghilev or Pavlova. It was only when Diaghilev specifically demanded from his collaborators a "Russian ballet," that, in 1909, a ballet was created on Russian myths to Russian folk songs and designed with peasant motifs in a "neo-nationalist" style; this was Firebird, the "first self-consciously 'Russian' ballet" (Homans, 2010, pp. 300-302).

Pavlova, who did not have Diaghilev's artistic resources, still managed to present a Russian dance in her programmes, usually balleticized folk dances in traditional Russian costume that she would dance herself (Money, 1982). She also changed the programmes according to what she thought her audiences might enjoy, such as presenting a faux Egyptian ballet in Cairo, and creating a ballet version of the Mexican hat dance for Mexico. Her Cairo audience took the ballet as a compliment, while Mexican audiences would throw their own sombreros onstage so that Pavlova would stomp on them on her toes (Money, 1982). Although they could not afford to fill the theaters for the rest of her engagement, Mexicans saw Pavlova's performances as legitimate dance theatre, and fashioned their own theatrical practice accordingly (Fisher, 2012).

In every new place, Pavlova hoped to find a "national school" that was that country's equivalent to the Imperial school in Russia, where the youth learned and honed their traditional dances or other performing art forms. She found the Japanese Noh and Kabuki, but also what she thought were undisciplined or casually mistreated practices in other areas, as well as a growing influence of Western modernization. She did not realize that some of the places she had visited had by then only started to imagine nation and what was national.

By 1916, Pavlova had performed in most of North America and opined that developing an "American ballet" was possible (Money, 1982, p. 242). She referred to American folk songs that could be the basis of grand balletic music suitable to their culture, similar to how Glazunov and Tchaikovsky were able to compose Russian ballet music. Later, as ballet did develop as a theatrical art form in the U.S., partly due to Pavlova's influence, some of the ballet music that successfully reflected America did base their rhythms on folk songs, as seen in Eugene Loring's Billy the Kid and Agnes de Mille's Rodeo, or on jazz, such as Jerome Robbins' Fancy Free and George Balanchine's Who Cares?'

In this vein, it should not be too strange for a "Filipino ballet" to develop over time, given how Filipinos are fond of the performance of fantastic storytelling, as seen from their oral traditions, and are fond of dancing, as seen from their ritual and social practices. Globalization transformed ballet from a Russian art form into a universal one. Any person of any nationality who could dance, who could move their bodies to music, would be able to learn ballet, and even master it. Evidence of this can be seen in the current high level of ballet practice in countries like the U.S., Cuba, Australia, Argentina, China, and the Philippines.

\section{The Filipinization of Ballet}

Anna Pavlova came to the Philippines in 1922 and performed at the Manila Grand Opera House. She arrived with her own performing troupe but did not appear in some of the early evening matinees because she was apparently under the weather. It was very hot in Manila when they came to perform and obviously uncomfortable for Europeans who are used to bracing winters. And yet, it was Pavlova, in her few actual performances, who ignited the feverish infatuation that Filipinos would have for ballet, an infatuation that would last for almost a hundred years.

As there is no accessible record of the programme that Pavlova's company performed in Manila, we can only imagine that it might have been a mixed bill that may have included ballets such as The Awakening of Flora, The Enchanted Lake and Russian Dance, which they performed in Japan, as well as Coppelia, Autumn Leaves and The Ondines, which they performed in Calcutta (Money, 1982). In any case, the diverse cultures that were presented in one evening may have fired up the imaginations of the Manila audiences, as they had in other venues.

Whether it was from these dances that she saw, or from further exposure to ballet performances as she sought a ballet education for herself, Anita Kane, who was identified as one of the girls injected with ballet fever after Pavlova danced in Manila, had come up with Mariang Makiling in 1939, a ballet about a popular Filipino mythical deity, to original composed music by Ramon Tapales. Although Kane was not Filipino by birth, she had grown up in Camarines Norte. She studied ballet with Katrina Makarova, a Russian emigre fleeing the revolution. One of the first women to form both a dance school and company in the Philippines, which she named Pamana Ballet, ${ }^{10}$ Kane presented ballets with Filipino themes as well as 
classical ballets to Filipino audiences. (Radaic and Villaruz, 1994). She would take her company on national tours, as well, which seems to have also been from Pavlova's example.

When Luva Adameit settled in the Philippines as another Russian emigré in 1927, she opened her own ballet school and was noted for also presenting ballets with Filipino themes, such as a work entitled Planting Rice performed on pointe shoes. If Adameit had been in Pavlova's company before and/or after the Asian tour, she might have had the opportunity to dance in Mexican Hat Dance, or Pavlova's ballets inspired by India, namely Hindu Wedding or Krishna and Radha, but then, the nature of ballet repertoire considered, any of the Orientalist works would have influenced Adameit to customize ballet to make it more palatable and familiar to a Philippine audience. She also had a ballet entitled Cariñosa, which is based on the Philippine folk dance of the same name, and is said to have balletized the folkloric steps, although the sway balance arms in Philippine folk dance, where the arms are held in a rounded shape and gently sway across the body and back again, resemble the classical ballet port de bras or movement of the arms, if a bit softer and more relaxed than its European counterpart.

Then and even now, Filipinos love ballet, but then Filipinos have always loved dancing. The most popular dances performed by folk dance troupes are those that exhilarate the audiences: a couple jumping over benches piled high on top of each other in Sayaw sa Bangko; young girls whirling around with either glasses of water, as in Binasuan, or a stack of clay pots, as in Sayaw sa Banga, on top of their heads; skillfully hopping or stepping over clashing bamboo poles as in both the rural Tinikling and the Maranao Singkil. Ballet was a similar spectacle of exhilaration, and was enjoyed not only by upper classes in the CCP, but also when brought on tour throughout the Philippines. Many members of these audiences who watch these ballets find a way to learn these exhilarating dances, whichever social status they may come from.

In the 21st century, many local ballet schools offer scholarship programs for the less fortunate, and scholarship programs have also been put up by the local governments of Manila, Quezon City, Mandaluyong and Las Piñas; many of today's Philippine ballet stars have come from these programs, including Victor Maguad and Ronelson Yadao of Ballet Philippines, and Peter San Juan, Lobreza Pimentel and Jared Tan of Philippine Ballet Theatre. Ballet Manila also has its own similar scholarship program. Instead of jumping over benches stacked at great heights, male ballet dancers have learned to throw their partners into the air and catch them into a fish dive or a turn. Instead of spinning dizzyingly with a glass of water on their head, Filipino ballet dancers have become adept at the fouettés en tournant, a whipping turn trick that is often the highlight of a classical ballet, or the tours a la seconde, which is the male version of this step.

As Niels Mulder (1997) says of Catholicism in the Philippines, the foreign culture could only take root if the receiving culture had a similar practice already in place. This concept of Filipino culture transforming foreign cultures in a localization process is echoed in Virgilio Enriquez's discussion of Pagkataong Pilipino or Filipino Personation (1980), as affected by the influence of foreign cultures through colonization or otherwise. Enriquez opines that foreign influence on Filipino-ness alters as it is received by Filipinos. It is this Filipino-ness that does the altering itself, as it actively interacts with American, Spanish, Japanese or any other culture from around the world, instead of simply reacting to it passively or altering itself to fit the foreign culture (p. 15). MCM Santamaria (personal communication, 2008) further explains this Filipinization by placing the Filipino in the center of the discussion, as the point of reference. Therefore, in the appropriation and adaptation of a foreign culture, "the acts examined in the process of selection, modification and signification are those of the Filipino."

After a hundred years of practice and development, ballet was modified and made significant in the Philippines by Filipinos themselves. Kane's and Adameit's students had become important ballet school directors and choreographers and producers, in turn teaching next generations of ballet dancer, who then taught the next generation, and so on. One of Kane's students, Tita Radaic, ${ }^{11}$ opened and ran the ballet school at St. Theresa's College in Quezon City; one of her students was Lisa Macuja ${ }^{12}$, who has the distinction of receiving a scholarship of the Vaganova Choreographic Institute and is the first foreigner to have been appointed soloist with the Kirov Ballet in 1984; these institutions are later incarnations of the Imperial school and Imperial Ballet at the Maryinsky Theater, respectively. ${ }^{13}$ As a celebrated artist in the USSR, Macuja fulfills Pavlova's legacy of globalization by coming full circle - Macuja enamoured the USSR audiences with her dancing, coming from a country that established ballet after being enamoured by its most famous ballerina.

Macuja returned to the Philippines in 1986, danced for the two ballet companies in residence at the $\mathrm{CCP}$, and later founded her own ballet company, Ballet Manila, which started as a touring company, 
performing ballet in its purest and highest level as an art form on the most unconventional stages all throughout the Philippines, just as Pavlova did when she decided to tour the world. Macuja's advocacy is to bring ballet to the people - to the non-elite masses who wouldn't normally be able to afford tickets to a ballet, but believing that the art form would still be appreciated. "Filipinos are naturally a very musical and artistic race," Macuja opines (personal communication, April 29, 2020). "And we love stories. Ballet is an artistic expression of the body to music that tells a story without having to say a single word."

In the repertoire of Ballet Manila, and also Ballet Philippines and Philippine Ballet Theatre, the three major ballet companies currently active in the country, are various ballets based on epics drawn from oral traditions or historical figures fighting a revolution against colonizing forces or depictions of ritual practices or other local narratives. These are created by local Filipino choreographers who are not merely following Petipa's or Fokine's template, but have mastered the art form well enough to make their own experimentations and explorations. Ballet is just their medium, and it has been transformed to adapt to a new way of moving.

This new way of moving can be seen in Tony Fabella's Fiesta, where he Filipinizes the pas de deux (dance for two) by inserting local courtship practices in the interactions of the three lead couples, courtship practices which are also seen in many Philippine folk dances. It can be seen in Eli Jacinto's Magdaragat (Seafarer), where dancers wield large bamboo poles as if oars to a boat that fishermen use to navigate the stage as open sea, where ballerinas as fish skitter beneath them. It can be seen in Agnes Locsin's Igorot, where the groundedness of the dances of the Cordilleran people are transported into the toe shoes of the ballerinas who bear all their weight onto the leg and into the pointed foot refusing to "rise" on relevé, and puncturing the earth instead. ${ }^{14}$ It can be seen in so many other Filipino ballets that were created through the years and repeated at regular intervals. The ballet, as are the choreographers and dancers, are Filipino.

The three ballet companies are adept enough to stage Filipino ballets with Philippine themes alongside the classics from Imperial Russia: Giselle, Swan Lake, even La Bayadere. Interestingly, because the Philippines does not have extensive cultural contact with India, the Philippine stagings of La Bayadere in 2003 and 2004 appeared "oriental" to Filipinos as well, with audiences finding the ballet mysterious and exotic, unexpected and different from other familiar icons of ballet as, say, swans.

\section{Conclusion: The Flight of Filipino Swans}

Swans had become so commonplace in ballets in the Philippines that after a handful of Filipino choreographers have exhausted experimentations that deconstruct the swan theme, many have opted not to use the concept of swans in future work. Sorilla's Requiem for a Cygnet (2013) is a contemporary ballet for three male dancers, barechested in tutus as swans dusted in talcum powder, which of course scattered on the floor and allowed them to swirl around gracefully in high attitude ${ }^{15}$ extensions. They juxtaposed bird gestures of pecking, scratching and unglamorously shaking "water" off their bent legs with the traditional balletic swan arms and poses. The end of the short ballet finds the "dying swans" writhing across the stage in bourrees, ${ }^{16}$ the prominent step of Fokine's The Dying Swan, before abruptly dropping to the floor, lifeless.

The Dying Swan, in its original form, has not been performed in the Philippines as much as Swan Lake or other similar classical ballets; it is not officially in the repertoire of the three ballet companies, although it has been in the personal repertoire of a couple of ballerinas. Carlos Garcia, who is internationally known as Imelda Hardtoes, danced a parody of The Dying Swan with Les Ballets Trockadero de Monte Carlo, Les Ballets Grandiva, and Ballet Eloelle during his 20-year career as a "ballerina." The repertoire of these drag ballet companies, which feature men performing ballerina roles en travesti and en pointe, are often comedic versions of well-loved ballets, but the level of dancing is never compromised for the comedy. Garcia, who trained in the Philippines with Ida Beltran and Jojo Lucila before auditioning for Trockadero, shares that The Dying Swan is "literally death on your toes," as the dancer barely ever alights from her bourrees (personal communication, April 28, 2020). That a male dancer can master ballet enough to dance difficult female roles en pointe and have a successful career with international touring companies must say something of the level of training available in that country. When watching Carlos Garcia, and the many accomplished ballet dancers in the Philippines, it is curious to think that ballet is still considered a "foreign" art form.

Macuja has performed The Dying Swan "some thirty to forty times..." during the last stretch of her long, celebrated career. She remembers seeing The Dying Swan when she was 12 years old, performed by Rosita Dureza at a festival by Ballet Federation of the Philippines at Folk Arts Center, and shares that "I always thought that I was not supposed to dance it until I was old enough, and experienced and 
accomplished enough to really appreciate and dance it well" (personal communication, 2020). Macuja first performed the solo much later in her career, when she was around 45 years old, in a mixed bill performance at the CCP Main Theater that also featured other internationally acclaimed Filipino artists, including singer Lea Salonga and pianist Cecile Licad.

Most recent to the writing of this paper, under quarantine lockdown from the COVID-19 pandemic, the Birmingham Royal Ballet had filmed a "Home from Home" video of their principal dancer, Celine Gittens, performing The Dying Swan from her home, with the ending rechoreographed by the company's artistic director, Carlos Acosta. He had wanted this performance for streaming at home represent a "dance about life, about hope." (BBC UK, April 8, 2020). The Dying Swan image indeed lends this effect of pathos, but the beauty of the swan, even in its final seconds, does inspire, whether the ending is changed or not.

Following this lead, American ballet dancers Misty Copeland and Joseph Phillips (2020) had organized Swans for Relief, a dance film of thirty-two ballerinas from all over the world, including the U.S., the U.K., South Africa, Norway, Russia, Cuba, France, Canada, Austria, Mexico, Denmark, China, and the Philippines performing a few seconds each of The Dying Swan to raise funds for dancers affected by the shutdown of theaters and cancellation of shows. In this film, they featured two Filipino ballerinas from Ballet Philippines, Denise Parungao and Jemima Reyes, as well as two Americans with Filipino heritage, Stella Abrera-Radetsky of American Ballet Theater, and Angelica Generosa of Pacific Northwest Ballet. This new aspect of technology has again redefined globalization, blurring borders and bringing together ballerinas from all over the world during a time when movement throughout the world is on pause.

How ballet is considered a popular art form all over the world today is not all of Pavlova's doing, but her contribution is remarkable, and deserving of little tributes by Filipino swans, both male and female. The existence of swans in the Philippines may be accidental. Ballet, however, after having been all over the world and settling wherever it is welcomed and applauded, is not.

\section{References}

Aquino, F. R. (1983). Philippine Folk Dances (Vol. 6). Privately Printed.

BBC UK. (2020, April 8). Carlos breathes new life into dying swan. BBC arts culture quarantine. https://www.bbc.co.uk/programmes/articles/2LtS2qKgXf737QdhRkt6h2N/carlos-breathes-new-life-intodying-swan

Browning, B. (2002). Global dance and globalization: Emerging perspectives. Dance Research Journal, 34(2), 12-13.

Clements, J. F., Schulenberg, T. S., Iliff, M. J., Billerman, S. M., Fredericks, T. A., Sullivan, B. L. \& Wood, C. L. (2019). The eBird/Clements checklist of birds of the world: v2019. https://www.birds.cornell.edu/clementschecklist/download/

Copeland, M. \& Phillips, J. (2020, May 7). Swans for relief. GoFundMe charity. https://charity.gofundme.com/o/en/campaign/swansforrelief

De Mille. A. (1980). America dances. Macmillan Publishing Co.

Enriquez, V. (1980). Pagkataong Pilipino. In Mercado, L. N. (Ed.), Filipino thought on man and society. Divine Word University Publications.

Erdman, J. (1987). Performance as translation: Uday Shankar in the West. The Drama Review: TDR, 31(1), 64-88. https:/doi:10.2307/1145766

Erdman, J. (1996). Dance discourses: Rethinking the history of the oriental dance. In Morris, G. (Ed.), Moving words: rewriting dance (pp. 288-304). Routledge.

Fisher, J. (2012). The swan brand: Reframing the legacy of Anna Pavlova. Dance Research Journal, 44(1), 51-67.

Giddens, A. (1990). The consequences of modernity. Stanford University Press.

Hamera, J. (2007). Dancing communities: Performance, difference, and connection in the global city. Palgrave Macmillan.

Homans, J. (2010). Apollo's angels: A history of ballet. Random House.

Kringelbach, H. \& Skinner, J. (2014). Introduction: The movement of dancing cultures. In Kringelbach, H., \& Skinner, J. (Eds.), Dancing cultures: Globalization, tourism and identity in the anthropology of dance (pp. 1-26). Berghahn Books.

Lico, G. R. (2011). On this site will rise: Nation-building and Marcosian architectures. In R. R. Cañete (Ed.), Suri sining: The art studies anthology (pp. 171-184). The Art Studies Foundation, Inc.

Lumbera, B. (2000). Writing the nation/Pag-akda ng bansa. University of the Philippines Press.

Money, K. (1982). Anna Pavlova: Her life and art. Alfred A. Knopf.

Mulder, N. (1997). Inside Philippine society: Interpretations of everyday life. New Day Publishers.

Radaic, F. L. \& Villaruz, B. E. S. (1994). Kane, Anita M. In Tiongson, N. G. (Ed.), CCP encyclopedia of Philippine art, dance, vol. 5, (pp. 214-215). Cultural Center of the Philippines. 
Roldán, C., Brauer, D. \& Rohbeck, J. (2018). Preface. In Roldán C., Brauer D., \& Rohbeck J. (Eds.), Philosophy of globalization (pp. I-VIII). De Gruyter.

Srinivasan, A. (1988). Reform or conformity? In Agarwal, B. (Ed.), Structures of patriarchy: The state, the community and the household in modernising Asia - women \& the household in Asia (pp. 175-198). Zed Books.

Villaruz, B. E. S. (1991). Sayaw: An essay on Philippine dance. In Tiongson, N. (Ed.), Tuklas sining: Essays on the Philippine arts (pp. 230-271). Sentrong Pangkultura ng Pilipinas.

Villaruz, B. E. S. (1994). The American colonial and contemporary traditions. In N.G. Tiongson (Ed.), $C C P$ Encyclopedia of Philippine Art, Dance, vol. 5, (pp. 46-59). Cultural Center of the Philippines.

Yamomo, M. (2018). Theatre and music in Manila and the Asia Pacific, 1869-1946: Sounding modernities. Palgrave Macmillan.

\section{Notes}

${ }^{1}$ In the essay being cited, Lico earlier defined "palingenetic" as "a form of utopianism which evokes the idea of rebirth or spiritual regeneration" (p. 172).

${ }^{2}$ See Money (1982), for more detailed information on Pavlova's life, career, and legacy.

${ }^{3}$ The organizers who booked her international performances also paid a stipend to the Maryinsky Theater to allow Pavlova and other dancers to a leave of absence from their duties at the palace. These leaves of absence were often approved by the Tsar himself, and Money notes that Tsar Nicholas II would acquiesce due to the favourable press reviews that Pavlova received, which directly brought glory to Russia.

${ }^{4}$ In Money's Anna Pavlova: Her Life and Art, he consistently refers to the ballet as The Swan, which is Fokine's original title. For this paper, I shall use the title The Dying Swan, as it is more known in the Philippines.

${ }^{5}$ See Srinivasan (1988) for more information on India's anti-dance or anti-nautch campaign.

${ }^{6}$ Movement vocabulary refers to the poses, steps, arm gestures, positions and all other movements used in a ballet. An enchainment is a short passage of these steps and gestures "chained" to each other.

${ }^{7}$ The dancer's legs push off the floor, one foot onto the tips of her toes while the other slides up the front of her leg to her knee and slides down behind her leg, closing them together to prepare the same execution with the other leg. This alternating movement is usually done in a brisk, rapid manner to show off the ballerina's strength and aplomb.

${ }^{8}$ Homans commented on the Russian-ness of the Sleeping Beauty as follows: "What made the ballet so Russian was the way it absorbed western traditions into a seamless Imperial style: Beauty was a Russian ballet about the French court designed by a Francophile Russian, choreographed by a Russified Frenchman to music by a Russian composer for an Italian ballerina." (Captioned in illustration insert 1, found between pp. 134-135)

${ }^{9}$ For a history of ballet in America, see Agnes de Mille's America Dances (1980).

${ }^{10}$ Pamana is a Filipino word that translates to "Heritage" in English.

11 "Tita" is her nickname, but while she is not called this by her students (they call her "Mrs. Radaic"), she is professionally known and referred to by this name. Her full name is Felicitas Layag Radaic, with Layag being her maiden name and Radaic as her married name, and is often referred to as 'Felicitas "Tita" Radaic' in most Philippine dance literature.

${ }^{12}$ Lisa Macuja is her stage name, but she is also known by her married name, Lisa Macuja-Elizalde.

${ }^{13}$ The institutions fell with the Russian empire in 1917, and were rebuilt later under the Soviet government. The Kirov Ballet is known in the USSR as the Maryinsky or Mariinsky Ballet.

${ }^{14}$ Sally Ness has described what she calls a successful fusion of ballet and ethnic Ifugao movement in Agnes Locsin's neo-ethnic ballet, Igorot

${ }^{15}$ A ballet pose where one leg supports the dancer as the other leg is held in a lifted position, extending outward from the body, either to the front, back or side; the knee is slightly bent and the leg is rotated so that the knee and the foot are almost aligned.

${ }^{16}$ Literally translated from the French as "to cram or stuff," bourrées are executed with the feet raised to full or demi (half) pointe, and legs pressed tightly together, one in front of the other in what is known as the fifth position of the feet, or in parallel, as the toes alternately pound into the floor with alternating feet. The effect should make the dancer appear to be fluttering across the stage with barely perceptible movement. 